\title{
P353: The problem of patient safety in the provinces of Maniema and south Kivu in the Democratic Republic of Congo
}

\author{
AK Mwadi , SEM Bdom, M Kavul, M Selua, A Ajfma \\ From 2nd International Conference on Prevention and Infection Control (ICPIC 2013) \\ Geneva, Switzerland. 25-28 June 2013
}

\section{Introduction}

Patient safety is now a global public health priority. In DR Congo, after several years of armed conflict in particular in the East, it is imperative to know the inventory of patient safety in a post-conflict situation in the country.

\section{Objectives}

To evaluate the perception and arrangements on patient safety by personal health care facilities in the eastern DR Congo.

\section{Methods}

Using a standardized questionnaire, interviews, focus groups and field visits were conducted with ten health centers randomly selected Uvira and Kindu in the provinces of Maniema and South Kivu.

Items focused on the organization of health, perception of patient safety and prevention of risk. The observation concerned the operating rooms, maternity wards, labs, sterilization and waste treatment.

\section{Results}

It was found: In knowledge: $80 \%$ interviewees are aware of the risks of nosocomial infections and $90 \%$ are not aware about the safety of patients, $62.5 \%$ believe that it is not a priority given insufficient resources, $100 \%$ believe that it is the responsibility of government authorities. Plan comments: No incinerator in $100 \%$ of the 10 facilities visited, Using disinfecting means: bleach as a disinfectant $(20 \%)$, soap powder $(80 \%)$ Lack of piped water $(100 \%)$ in operating rooms, care and childbirth; Presence sterilizing equipment: poupinel oven (10\%),

RIPAQS-DRC, Kinshasa, Congo, The Democratic Republic of the charcoal autoclave (10\%), lack of sterilization procedures $(100 \%)$.

\section{Conclusion}

The safety of patients is not known and neither a major concern in the structures hosting visited sick and family members who make long journeys in search of care.

\section{Disclosure of interest}

None declared.

Published: 20 June 2013

doi:10.1186/2047-2994-2-S1-P353

Cite this article as: Mwadi et al:: P353: The problem of patient safety in the provinces of Maniema and south Kivu in the Democratic Republic of Congo. Antimicrobial Resistance and Infection Control 2013 2(Suppl 1): P353.

Submit your next manuscript to BioMed Central and take full advantage of:

- Convenient online submission

- Thorough peer review

- No space constraints or color figure charges

- Immediate publication on acceptance

- Inclusion in PubMed, CAS, Scopus and Google Scholar

- Research which is freely available for redistribution

Submit your manuscript at www.biomedcentral.com/submit

\section{Ciomed Central}

